\title{
Barium bright and heavy
}

\author{
Katharina M. Fromm relates how barium and its ores went from a magical, glowing species that attracted \\ witches and alchemists to components in a variety of compounds that are key parts of modern life.
}

\begin{abstract}
$\mathrm{n} 1602$, the shoemaker and alchemist Vincenzo Casciarolo became fascinated by an ore - named Bologna stones or lapis solaris - containing small shiny crystals that continued to glow long after having been exposed to daylight, which captivated witches and alchemists alike. Ulisse Aldrovandi published this phenomenon, but it was so extraordinary that scientist Giulio Cesare Lagalla remained unconvinced, even when Galileo Galilei presented him with one of the stones. Investigating further, Lagalla observed that persistent luminescence was mainly observed after calcinations of the stone, as he
\end{abstract} described in his book De Phenomenis in Orbe Lunae, 1612. The luminescence of the Bologna stones was thought to originate from baryte $\left(\mathrm{BaSO}_{4}\right)$, principal component of the mineral, but it was recently shown to arise from $\mathrm{Cu}^{+/ 2+}$ doped $\mathrm{BaS}$, which was also present ${ }^{1}$.

In 1774, the Swedish chemist Scheele discovered barium oxide in gypsum, and in 1808 Sir Humphrey Davy isolated some metallic, but impure, barium. It was Robert Bunsen who obtained the metal in pure form by electrolysis of molten $\mathrm{BaCl}_{2}$ in 1855. Element 56 went on to play important roles in other scientific discoveries - some 50 years later, Marie Curie discovered the heavier atom radium in a mixture with barium. In 1938, when Otto Hahn and Fritz Strassmann found barium among the products obtained on bombarding uranium with slow neutrons they, together with Lise Meitner, concluded correctly that the nucleus of uranium had been fissioned.

Metallic barium is very reactive with air and water, and serves in vacuum tubes and pipes to remove unwanted gases, suppressing high pressures and preventing blowouts. The once mysterious baryte main source of barium and its compounds - is mass-produced today (more than 5 million tons in 2010) to serve in the oil industry, as a weighting agent that increases the density of drilling fluids in oil and gas

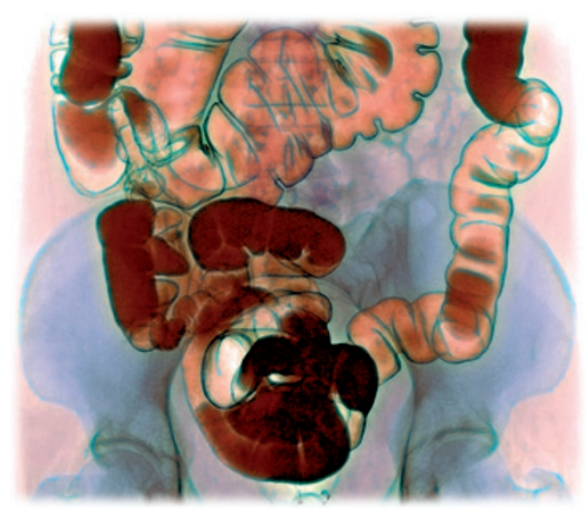

explorations. In fact, this high density gave barium its name, after the Greek word ßapús (barys) meaning 'heavy'.

Baryte is found in many, and varied, materials: as a white pigment in photographic papers; as filler in paints, plastics and automobile coatings for smoothness and corrosion resistance; in high-density concrete and radiation-shielding cement; and even for medical applications. Indeed, barium sulfate can be introduced in the digestive system, from either end and with notable discomfort, as a contrast agent for X-ray scans to detect stomach or bowel disorders. Although barium ions are toxic - they can severely interact with the calcium and potassium metabolic reactions, inducing cardiac irregularities and tremors that can cause paralysis - barium sulfate's insolubility ensures that it can be ingested safely. In contrast its carbonate counterpart, which dissolves in stomach acid, is put to use in rat poison. Despite this toxicity, barium uptake and accumulation has been observed in some plants; the green algae Chlorophyta even seems to need barium to grow well, but its role remains unclear ${ }^{2}$. Brazil nuts can contain up to $1 \%$ of barium, as well as some selenium (also toxic in excess), and should be consumed with moderation ${ }^{3}$.

Another noteworthy salt is barium dihydroxide. On mixing it with an ammonium salt, for example ammonium chloride, a strongly endothermic reaction occurs between the two solids that produces a liquid $\left(\mathrm{BaCl}_{2}\right.$ and water) and gaseous ammonia; water placed under the reaction vessel will freeze - making for a striking demonstration experiment. $\mathrm{Ba}(\mathrm{OH})_{2}$ is also used as a strong base $\left(\mathrm{p} K_{\mathrm{B}}\right.$ of -2$)$ in organic synthesis to hydrolyse esters and nitriles ${ }^{4}$; as nanoparticles it is used to restore old wall frescoes by combating gypsum (calcium sulfate) through barium sulfate formation ${ }^{5}$. This method, developed after a catastrophic flood in Florence in 1966, has been used successfully on fourteenth- to eighteenthcentury frescoes, for example in Venice, and in the cloister of Brixen in South Tyrol, Italy.

The mineral witherite $\left(\mathrm{BaCO}_{3}\right)$ is also commonly used. Synthesized from barium sulfide and carbon dioxide it serves as ingredient in glazes and, combined with other oxides, produces unique colours. Other barium-containing oxides show attractive properties $-\mathrm{BaTiO}_{3}$ is a photorefractive, ferroelectric and piezoelectric ceramic, and $\mathrm{YBa}_{2} \mathrm{Cu}_{3} \mathrm{O}_{7}$ a high-temperature superconductor. Barium halides are useful for preparing low-temperature precursors for such oxide materials ${ }^{6}$.

Amongst the diverse applications that now involve barium, one has remained particularly close the original attraction it exerted through its intriguing glow - barium nitrate and chloride salts serve to endow fireworks with striking green colours.

\section{KATHARINA M. FROMM is in the}

Department of Chemistry, University of

Fribourg, Chemin du Musée 9,

$\mathrm{CH}$-Fribourg, Switzerland.

e-mail: katharina.fromm@unifr.ch

\section{References}

1. Lastusaari, M. et al. Eur. J. Mineral. 24, 885-890 (2012).

2. Wilcock, J. R., Perry, C. C., Williams, R. J. P. \& Brook, A. J. Proc. R. Soc. Lond. B 238, 203-221 (1989).

3. Goncalves, A. M., Fernandes, K. G., Ramos, L. A., Cavalheiro, E. T. G., Nobrega, J. A. J. Braz. Chem. Soc. 20, 760-769 (2009).

4. Durham, L. J., McLeod, D. J. \& Cason, J. Org. Synth. 38, 55 (1958).

5. Giorgi, R., Ambrosi, M., Toccafondi, N. \& Baglioni, P. Chem. Eur. J. 16, 9374-9382 (2010).

6. Gschwind, F., Sereda, O. \& Fromm, K. M. Inorg. Chem. 48, 10535-10547 (2009). 